\title{
Myanmar's Rohingya Refugees in Malaysia: EDUCATION AND THE WAY FORWARD
}

\author{
Hema Letchamanan ${ }^{\mathrm{a}}$ \\ CRICE, University of Malaya
}

\begin{abstract}
The Rohingya, a persecuted minority, has faced decades of harsh treatment and made stateless by the military government in Myanmar. To escape from this severe repression, most Rohingya flee to Bangladesh, Thailand or Malaysia. In Malaysia, this community has been living invisibly for more than three decades. Just like other refugees, the Rohingya are not allowed to work legally and do not have access to free healthcare and education in this country. Many of these refugee children learn in the learning centres run by the community with the help of UNHCR and local NGOs and in madrasah ${ }^{1}$ after school hours. Nevertheless there is a huge gap in education for these children, especially for girls and boys over 15 years old. This paper addresses the gap, discusses the teaching and learning provided in the refugee learning centres and the future of these refugee children in Malaysia.
\end{abstract}

KEYWORDS: refugees, learning centres, quality, education.

\section{Introduction}

Everyone has the right to education. Education shall be free, at least in the elementary and fundamental stages...Education shall be directed to the full development of the human personality and to the strengthening of respect for human rights and fundamental freedoms. It shall promote understanding, tolerance and friendship among all nations, racial or religious groups, and shall further the activities of the United Nations for the maintenance of peace.

(Article 26, The Universal Declaration of Human Rights)

The latest available figure of refugees in the world is 10.4 million in the beginning of 2012 (UNHCRb, 2013) with a further of 4.8 million Palestinian refugees living in camps set up since 1949. Conflicts have lasting impacts on people who have been displaced either internally, seeking refuge in another country or who return home from exile due to man-made disasters such as civil wars or natural disasters such as earthquakes. Emergencies cause major disruption in schooling (Sinclair, 2007). In situations such as in Myanmar, children in conflict areas do not have access to schools due to security problems, lack of educational resources and infrastructure deterioration. Therefore, appropriate educational experience should be made possible to the excluded and marginalised groups who have no access to the mainstream education (Brock and McCorriston, 2008). Education provided for children affected by emergencies is defined by INEE $(2007$, p.1) as:

Education that protects the well-being, fosters learning opportunities and nurtures the overall development (social, emotional, cognitive, physical) of children affected by conflicts and disasters.

Education provided during emergencies can help children to (Sinclair, 2007: 52-53)

a) provide a sense of normality;

b) restore hope through access to the 'ladder' of education;

c) support psychological healing from traumatic experiences through structured social activities in a 'safe space';

d) convey life skills and values for health and prevention of HIV/AIDS, gender equality and prevention of gender-based violence, conflict resolution, peace-building, responsible citizenship and environmental awareness

correspondence can be directed to: crice@um.edu.my 
However, education and refugees are increasingly seen as being on opposing ends of a spectrum. The Rohingya are acutely aware of this having earned the dubious distinction of being "stateless". Their country of origin, Myanmar, refuses to recognise them leaving them with no option but to look elsewhere for support. As is often the case, the children whose lives are forcibly disrupted, are the direct and indirect victims of this ethnic discrimination. This paper charts the situation of Rohingya refugees in Bangladesh, Thailand and Malaysia where they are mostly found. This situation directly influences the provision of education for the refugee children. The second part of this paper discusses the education provided in Malaysia, and the quality of it by using the INEE (Inter-Agency Network for Education in Emergencies) Minimum Standards Framework. If education is indeed the central pillar of humanitarian response (Brock, 2011) then the Rohingya situation is dire as this paper will show that the level of education of Rohingya students is far below what is recommended by the Framework. The INEE Framework is used to enhance the quality of education and increase access to safe and relevant learning experience as it provides the minimum education standards required for children affected by calamities. This Framework is also used globally for programme and policy planning, advocacy and preparedness in order to achieve the Education for All (EFA) goals (ActAlliance, 2011). This paper will suggest recommendations at the end to improve the Rohingya situation. The recommendations are not only for the Rohingya but also other refugees who have made Malaysia their temporary or permanent base.

\section{The Situation in Rakhine State Today}

To understand the unrest in the state of Rakhine today, it is important to begin with its history. Rakhine (formerly known as Arakan) is a state in Myanmar on the western coast. It borders with the Chin State in the north and the Ayeyarwary, Bago and Magway regions in the east. The Bay of Bengal is in the west and Bangladesh's Chittagong division to the northwest. The State's population is as 3, 836, 000 in 2010 according to the official Myanmarese figures (SPDC, 2010). It is important to note however that there has been a lack of proper census in this state, and the country as a whole since 1983; hence the figure may be higher than stated in official documents. The Rakhine State, as other parts of Myanmar, has a diverse population. The ethnic Rakhine constitute to the majority of the population, with a number of other ethnic minorities such as the Chin, Dainet, Mro, Khami and Rohingya. The two main religions practised by the people in this state are the Theravada Buddhism and Sunni Islam. The Rohingya are the Muslims of Mayu Frontier area, present-day Buthidaung and Maungdaw townships in Rakhine which borders with Bangladesh (Chan, 2005). After the riots of 2012, various local surveys conducted found that the Rohingya Muslims constitute to about $40.75 \%$ of the population in Rakhine state, which makes them the second largest ethnic group after the Rakhine Buddhists (The Economist, November 3 2012).

The 1982 Burma Citizenship Act does not recognise the Rohingya as an ethnic group, which has left them officially stateless for decades. They are regarded in Myanmar as immigrants from Bangladesh even though they have long lived and born in the country. Bangladesh, on the other hand, does not recognise them as their people. United Nations High Commissioner for Refugees (UNHCR) and Médecins Sans Frontières (MSF) (also known as Doctors without Borders; an international medical and humanitarian aid organisation) describes the Rohingya as one of the most persecuted people in the world (Robinson and Rahman, 2012). Their struggle and oppression has been one of the most under-reported humanitarian crises in the world. The international media and community have practically ignored the situation of these people (MSF, 2010). Violence erupted in June 2012 in north western Rakhine state following the rape and murder of a Buddhist Rakhine woman allegedly committed by three Muslim Rohingya men. The quasi-military government of Myanmar declared a state of emergency, and the military went on to commit acts of "violence and other human rights abuses against the Rohingya including killings and mass scale arrests of Rohingya men and boys in North Rakhine State" (Refugee International 2012). Human Rights Watch 2012 accused the security forces in Myanmar of 'ethnic cleansing' against the Rohingya. Tensions were reignited again in October 
2012 and more clashes happened in March 2013. Media reported that 192 people were dead and more than 140,000 Rohingya had been forcibly displaced (Radio Free Asia, April 29, 2013). Those who have been displaced have been denied access to humanitarian aid and not allowed to return home (Human Rights Watch, 2013). At the time of writing, this state is still in disquiet.

The prolonged unrest has left many Rohingya fleeing the Rakhine state for fear of life to mainly Bangladesh, Thailand and Malaysia due to religion and geographical factors. They face different sets of challenges in these three countries, including the way and quality of life, living space, and educational experience. For example, the Rohingya refugees live in makeshift camps in Cox Bazaar in Bangladesh but in Malaysia, they live in rented flats in cities. Bangladesh, Thailand and Malaysia are not parties to the 1951 Convention relating to the Status of Refugees nor to its1967 Protocol, just as most South-East Asian countries (UNHCR, 2011). This means refugees, the Rohingya including are not entitled to any formal protection from these countries. The section below details the life of Rohingya refugees and educational experience provided for the children in these three countries

\section{Rohingya Refugees in Bangladesh}

Many Rohingya sought refuge in Bangladesh because of their similar social, ethnic and religious characteristics, in particular their common observance to Islam. After a major influx of refugees in $1992^{2}$, the Bangladeshi authorities have forced them back to Myanmar, but they again returned to try to seek refuge and self-settle in the South-eastern parts of Bangladesh (Haque, 2011). According to UNHCR reports, there were some 29,000 recognised refugees in camps in Kutupalong and Nayapura in Cox's Bazaar District in south- eastern Bangladesh (see table 1) and an estimated 36,000 unrecognised refugees who are in makeshifts with limited humanitarian aid access in the sub-districts of Teknaf and Ukhia (Kiragu, Rosi and Morris, 2011). It is also reported that there are over 200, 000 undocumented Rohingya refugees living within the community.

Table 1: Myanmar Refugees in Bangladesh, 2006-2010

\begin{tabular}{llllll}
\hline Kutupalong camp & 2006 & 2007 & 2008 & 2009 & 2010 \\
\hline Age group 0-4 & 1730 & 1944 & 2158 & 2164 & 2074 \\
Age group 5-17 & 3974 & 4090 & 4340 & 4475 & 4646 \\
Age group 18-59 & 4198 & 4439 & 4335 & 4408 & 4514 \\
Age group 60+ & 242 & 235 & 214 & 204 & 235 \\
Total all age groups & 10,144 & 10,708 & 11,047 & 11,251 & 11,469 \\
Nayapara camp & 2006 & 2007 & 2008 & 2009 & 2010 \\
Age group 0-4 & 2866 & 2898 & 3206 & 3122 & 2905 \\
Age group 5-17 & 6205 & 6473 & 6840 & 6946 & 7316 \\
Age group 18-59 & 6560 & 6939 & 6704 & 6713 & 6962 \\
Age group 60+ & 379 & 369 & 326 & 310 & 364 \\
Total all age groups & 16,010 & 16,679 & 17,076 & 17,091 & 17,547 \\
\hline
\end{tabular}

(Source: Kiragu, Rosi, Moris, 2011)

Bangladesh is not party to the 1951 Refugee Conventions or its 1967 protocol. It is also not a party to the 1954 and 1969 Statelesness Conventions. Therefore, the Rohingya lack of support for proper housing, healthcare and education. They are not protected from the law and authority and have an economic condition worse than any other community in Bangladesh (Haque, 2011). Children under the age of 18 make up 50\% of the refugee community living in camps in Cox's Bazaar (see Table 1), and a similar proportion for the undocumented refugees although official statistics is not available (Feeny, 2001). The Bangladeshi government had not allowed schooling to take place in 
the camps until 1997, but even now it is non-formal (primary only)and of low quality, taught by the refugee volunteers (ibid). There is no provision for secondary and tertiary education. For years, these children have been deprived of proper schooling which has greatly reduced their opportunities to overcome their economic situation and lead a better life by developing their academic and vocational skills. They are often subjected to human trafficking, rape, early marriage, teenage pregnancy and domestic abuse. In 2000, Concern Worldwide, a non-governmental organisation working with the poorest people in several countries, has been given the responsibility to reshape the educational programmes provided in the camps in Cox Bazaar. They constructed 14 new schools with 5 classrooms in each were in both camps. Refugee teachers were given incentives in the form of monthly provision and clothes as a form of motivation to teach. Parents were also encouraged to send their children, especially girls to school. Students attend formal assemblies where they sing the national anthem of Myanmar and awareness on health and clean sanitation was raised (Concern Worldwide Bangladesh, 2001). Although these certainly were a boost to an otherwise poorly maintained school, problems in terms of quality, teaching materials, curriculum and dropout rates still persist.

\section{Rohingya Refugees in Thailand}

Thailand has nine official refugee camps built along the Thai-Myanmar border, housing more than 140, 000 refugees (Oh, 2011). Most of these refugees are from the Karen and Karenni ethnic groups. In total there are 70 schools in the seven Karen camps and 11 in the two Karenni camps in the north. Pre-primary, primary, secondary, vocational and adult learning are made available in these camps. Progress is also on the way to certify the learning in these camps. Thailand like many other countries in Asia is not a signatory to the 1951 Convention relating to the Status of Refugees. It does nonetheless allow local and international aid organisations to operate in these camps where essential services are provided for shelter, food, water, sanitation and education. However, the Rohingya refugees do not benefit from these services, in particular education. Since the conflict in the state of Rakhine in June 2012, more than 6,000 Rohingya 'boat people' have arrived in Thailand (Reuters, February 9, 2013). The Thai Department of Foreign Affairs announce on January 25, 2013 that the Rohingya refugees will be allowed to stay in the shelters in the country for six months while the government prepares a new policy (O'Toole, February 12, 2013). The Thai government has also agreed to provide basic humanitarian aid for these people, however, education not being part of it.

\section{Rohingya Refugees in Malaysia}

The Rohingya have been seeking refuge in Malaysia since the 1980s. As of end of April 2013, there are some registered 28,120 Rohingya refugees in Malaysia (UNHCR, 2013a) and a large number remain unregistered, with the refugee community themselves estimating the number of unregistered to be the same as registered (personal communication, 2013). Refugees in Malaysia do not live in camps. They live within the local community, as invisible as they could. They usually live in cramped low-cost flats in the city where they could find odd jobs in the restaurants and factories. Many Malaysians are themselves not aware of these refugees and often mistaken them for illegal immigrants (Letchamanan, 2010). A huge number of Rohingya children are born in this country, but since Malaysia does not practise the principle of jus soli, citizenship is not granted to these children. Malaysia is also not a signatory to the 1951 Convention relating to the Status of Refugees. The Malaysian government is allowing the refugees to stay in Malaysia on humanitarian grounds while waiting to be resettled to a third country. The Rohingya were given a reprieve in 2006 when the Malaysian government began issuing IMM13 permits which offered some form of legitimacy. This would protect them from being harassed by the authorities or even being arrested. Unfortunately the efforts to legitimise the Rohingya were halted when the government decided to relook at the overall refugee situation. This has since caused them undue distress and prevented them from integrating into Malaysia society. The UNCHR has also adopted a wait and see approach 
since December 2005 and only make exceptions for cases considered to be vulnerable (Garcia and Olson, 2008; Rahman, 2009).

Many refugees from Malaysia have been resettled to a third country over the years, with the help of UNHCR and other international aid and faith-based organisations. The Rohingya however have not been included in this resettlement process. From the interviews conducted by the author, the refugees believe the third country, usually either Australia, Canada, the USA, Germany or France refuse to accept the Rohingya because of their religion. Another fact that hinders the resettlement process for this community is because many of them are married to Muslim migrants from Indonesia who overstay in Malaysia. At least eight refugees whom the writer met during interviews ${ }^{3}$ are married to Indonesians.

The ethnic-based clashes in Myanmar recently spilled over to Malaysia with several clashes between the Buddhist and Muslim Myanmarese have occurred in the city, resulting in two deaths and another two in critical condition (The Star, June 11, 2013). The Malaysian police have been quick in detaining some 1,000 Myanmarese workers following this dispute; mostly refugees working illegally.

The Rohingya, along with other refugees are not allowed to work and do not have access to free healthcare and public education in Malaysia. UNHCR with the assistance from local nongovernmental and faith-based organisations operate learning centres for refugee children. There are about 120 such learning centres in West Malaysia, mostly in Klang Valley, Johore and Penang. Majority of the teachers in these schools are from the refugee communities themselves with local and foreigners volunteering on regular basis. These learning centres are located also in flats, and are usually cramped with 60-100 children, although there are centres with smaller number of children. Learning centres are opened where there is a big number of refugee community living in that area.

\section{Education for Rohingya Refugees in Malaysia}

In respect of the educational dimensions of conflict and post-conflict situations (Davies, 2004), they are part of 'education in emergencies' that is, in turn, part of 'education as a humanitarian response' (Brock, 2011). Many research have been done on education for refugees in their places of resettlement, but in comparison, research on the provision of education in places of temporary settlements is less comprehensive (Preston, 1991). Malaysia is a temporary settlement for refugees as it only allows them to stay on humanitarian grounds while waiting to be resettled or repatriated, hence providing limited or no opportunities and benefits for them. However, education is essential in ensuring stability and a sense of normalcy for the refugee children. It is also important for a better future either when repatriated or resettled to a third country.

The Rohingya refugees have been living in Malaysia for more than two decades without proper access to basic healthcare and education. This means a generation without formal education. Many adult Rohingya refugees are illiterate, with some able to read and write Jawi and after years of living in Malaysia, the Malay language. The Rohingya refugee children attend learning centres operated by the community and faith-based organisation with the assistance of UNHCR. For the Rohingya refugee community, the purpose of education is for their children to succeed and have a better life than theirs.

Our students are interested in learning. We as the parents want our children to succeed so that they have a better life. Not like ours. I can't read and write. I don't want my children to be like me too. (Refugee parent, from interview, translated)

\section{Methodology}

For the purpose of this research, the writer visited two learning centres for the Rohingya children; one operated by Taiwan Buddhist Tzu-Chi Foundation located in Cheras, Kuala Lumpur and the other by the Rohingya community themselves in Puchong, Selangor (Rohingya Community School Puchong). Semi-structured interviews ${ }^{3}$ were carried out with the two principals and three 
teachers of these learning centres. The first learning centre has 116 students with four teachers and the second has 31 students with one teacher. The principal and three out of four of its teachers in the Taiwan Buddhist Tzu-Chi Foundation School are Malaysians. The teacher and principal of the Rohingya Community School Puchong are refugees themselves.

In both the learning centres, UNHCR assists by providing textbooks, compensation for the teachers and teacher training. The children are taught Malaysian syllabus using books given by UNHCR. They learn Mathematics, English, Science and Malay Language. In Taiwan Buddhist Tzu-Chi Foundation School, there are two sessions; morning and afternoon separated according to grades with the older children attending the morning session and the younger ones in the afternoon. The Rohingya Community School Puchong does not have the facilities to conduct classes for different levels. All students aged six to thirteen attend the same class together. Monthly compensation is given to the principal and teachers in the form of cash, but from the interviews, it was gathered that this compensation is very little and insufficient. Teacher training is provided to all refugee school teachers by Dignity School with the assistance of UNHCR. Trainings provided include pedagogy and leadership.

It is important to acknowledge the work done by UNHCR, their implementing partners like the Taiwan Buddhist Tzu-Chi Foundation and also the community in their initiative to educate the children. They operate with limited resources and more often than not they too are ill-equipped to provide teaching and learning. Nonetheless to say, a huge gap remains in the quality of education provided in these centres.

The underlying argument is one that contrasts access to education and access to quality education. While proponents of access retention and completion were successful during the 1990s, the tough process has undergone a subtle but significant shift. Where access is a given, the next step is to focus on quality with a long term view. The demands of the modern and mobilised workforce in particular are reflected in the 2000 Dakar Framework for Action where the explicit goal is quality of education:

(...) improving all aspects of the quality of education and ensuring excellence of all so that recognized and measurable learning outcomes are achieved by all, especially in literacy, numeracy and essential life skills. (The Dakar Framework for Action, 2000:8)

Providing education is important, but more important than that is to provide quality education that would benefit these children in the future. Education, as much as it needs to solve the immediate problems, need also address the long term goals and prepared the refugee children to be independent and uplift them from poverty. Without this, they will go on living in a state of limbo for generation to come. This is especially pertinent in the case of the Rohingya refugees because they are not resettled to a third country. Nor are they repatriated because their country of origin has declared them stateless. For that, many have come to call Malaysia their home.

The INEE Minimum Standards Framework is used in this paper to benchmark the quality of education provided and received by the Rohingya refugee children. This framework is used as a basis because it provides the minimum standards that each learning centre should have to provide quality education. Quality in education can be understood in many different ways, depending on the values and priorities of the host country, international organisations and other stakeholders. For this paper, 'Quality education' is defined as education that is available, accessible, acceptable and adaptable (INEE, 2010). This definition of what a quality education should be, is indeed apt for the refugee children living in Malaysia. The INEE Minimum Standards are derived from the Sphere Project's Humanitarian Charter. This is based on the principles and provisions of international humanitarian law, international human rights law, refugee law and the Code of Conduct for the International Red Cross and Red Crescent Movement and Non-Governmental Organisations (NGOs) in Disaster Relief. The Humanitarian charter has the sole purpose to ensure that all people impacted by any kind of disaster, natural or otherwise are to receive basic relief that guarantees their safety and dignity despite unwillingness or neglect by relevant authorities. In such cases, the Charter provides guidelines that 
clearly state the legal obligation of parties concerned and will ultimately ensure that some form of Humanitarian relief is provided to victims by other organisations.

The INEE Minimum Standards (2010) are organised in four main domains; access and learning environment; teaching and learning; teachers and other educational personnel and education policy, with foundational standards as the fifth domain which includes coordination and community participation, and applied across all the other four domains.

\section{Access and Learning Environment}

This domain focuses on access to safe and relevant learning opportunities. It also highlights other important sectors such as health, water and sanitation, nutrition and shelter that help to enhance security, safety and physical, cognitive and psychological well-being of the Rohingya refugee children. Quality is ultimately defined by how much learning that takes places, but for that to happen, the conditions that allow learning has to be firstly created. Most of these learning centres are located in places where there is a high density of Rohingya refugee community. Children are usually sent to these centres by their parents. Some centres do provide transport where children are picked from their houses. From interviews, the writer also found that some older children do walk to the centres although this is not encouraged because they may be detained by the police on their way. The learning centres for refugee children in Malaysia are usually flats and houses converted into a few classrooms. It is important to distinguish between a school and a learning centre. These learning centres do not have facilities such as field, proper and comfortable classrooms, library and laboratories that a typical school would normally have.

The learning environment in these centres is not conducive for learning. All the teachers whom the writer interviewed felt the classrooms are too crowded no proper partitions for the different classrooms. This increases the noise level and both the teachers and the students find it hard to concentrate in such environment. The Rohingya Refugee School Puchong had only one teacher for all of its 39 students who aged from five to fifteen and are at different levels but put in the same classroom to learn because of lack of facilities and teachers. The principal of this school mentioned that it was not possible for one teacher to cater to the varying needs and levels of these students at the same time. There is no play area for these children, although some do have access to the field or playground in the neighbourhood. Recent work in cognitive science shows that intelligence is not fixed genetically, and that it can be significantly enhanced when the child is put in a nourishing, supportive and sensory-rich environment (Perkins, 1995; Levinger, 1994). This scientific evidence undermines many of the traditional assumptions governing approaches to the disadvantaged, who were treated, if at all, through the application of special educational programmes (Bereiter and Scardamalia, 1993). What is now recognised is that all children respond well in a loving, nourishing, challenging and stimulating learning environment (Gardner, 1983, 1993; Levinger, 1994). For these Rohingya refugee children to develop in a holistic way, a conducive learning environment is pertinent. Although not ideal classrooms, realistically the learning centres should have separate classrooms with proper lighting and ventilation for each level. Classrooms should also be able to accommodate the number of students in each level. In levels where there are more students, bigger space should be used as classrooms.

\section{Teaching and Learning}

These standards focus on critical elements that promote effective teaching and learning, including curricula, training, professional development and support, instruction and learning processes, and assessment of learning outcomes. The learning experience of all refugee children should be the main concern of all stakeholders. What are they learning? Who is not learning and why? The latter is seldom addressed as most are only concerned with the children who are learning. At many times, children can attend the learning centres yet not learn anything. Teaching and learning should address the children's different learning needs and provide opportunities that attract them 
to participate actively in groups and individual learning activities (American Institute for Research, 1999). More importantly, what the Rohingya refugee children learn in the centres should be relevant for them and they should be able to gain essential skills for effective life-long learning. As mentioned earlier in the paper, the students are taught the Malaysian syllabus using workbooks given by UNHCR. However, from beginning of 2013 the publisher has stopped printing books in English since the medium of instruction in all national schools in Malaysia has been changed to Malay language, and therefore the publisher has stopped supplying books to UNHCR. The learning centres have not received any books from UNHCR for the year 2013. From the interviews conducted, all teachers answered that they teach the Malaysian curriculum. This in itself is a misconception that the learning centres have because they are not teaching the Malaysian curriculum, but the workbooks by private publishers which are aligned with the syllabus taught in the public schools in Malaysia.

How relevant is this syllabus for these children is something pertinent to be pondered. They are not allowed access to public schools, nor can they work legally in this country. Hence, the question of what will the use of teaching Malaysian syllabus to these children be arises. An appropriate curriculum should be developed or adopted for these children; a curriculum which will prepare them for the challenges in a rapidly evolving world. The content should incorporate the acquisition of literacy, numeracy and life skills as well as knowledge in gender, HIV/AIDS prevention, health and peace (Sinclair, 2007). Vocational and technical skills are useful for adolescents who will leave the centres once they reach the age of fifteen or sixteen to work and contribute to the family. The curriculum should also teach the children their rights as refugees so that they are aware of them even when they resettle to a third country (ibid). The Rohingya refugee children should not grow up to live the same way as their parents do.

\section{Teachers and Other Education Personnel}

Standards in this domain cover administration and management of human resources in the field of education. This includes recruitment and selection, conditions of service, and supervision and support. Quality education can only be achieved if the teachers are well-equipped and motivated to teach. It is important to note that most of the teachers in these learning centres are refugees themselves. They too have gone through the conflicts, and therefore may need psycho-social counselling along with other trainings provided. At present, all the teachers except for one whom the writer interviewed from both schools have attended teacher trainings organised by UNHCR. These trainings provide input on creating lesson plans, fun activities for the children and leadership and management skills. The teachers felt these trainings have given them some idea and insights into developing lessons. However, quality improvement is a package because the factors are not independent of each other (Craig, 1995). Teacher training is unlikely to improve the quality of education provided if appropriate and relevant materials and equipment are not provided. Many of the refugee teachers are high school leavers or university graduates from their country of origin. They do not have the experience or pedagogical skills to teach. They also lack the English language skills. The trainings given are not sufficient to cope with the lack of these skills. Another important motivation to teach will be the compensation. The little compensation given is insufficient because these teachers also have their own families that they have to provide to. In the cases where a refugee teacher is unregistered with UNHCR, compensation is not given.

Volunteers also form an important part in improving the quality in education. The volunteers in these centres are Malaysians and foreigners. They work with the children on certain days in a week by organising activities and games. Some volunteer on regular basis to teach Mathematics, Science or English. As mentioned by a Korean volunteer teacher in one of the learning centres:

I have been volunteering here for the past one year. I teach them Maths and Science. It is difficult to teach with limited resources but I work with what I have. I also create my own materials. I enjoy teaching these refugee children although we had language barrier in the beginning. 
The efforts by the volunteers certainly need to be recognised and applauded. However, in some centres, it is difficult to get volunteers or to have committed volunteers. Perhaps, UNHCR as the main organisation involved could source for more committed volunteers and even provide transportation for them to go to these centres as some are located in quite remote parts of the city. By doing this, the centres will always have a pool of volunteers and more quality activities can be carried out.

\section{Education Policy}

Standards in this domain focus on policy formulation and enactment, planning and implementation. Education policies for the Rohingya refugee children should be formulated and implemented by UNHCR as the international organisation which deals with refugees. Others such as non-governmental organisations, faith-based organisations and educationists could assist UNHCR to formulate policies. Fundamental to a quality education is relevant and effective policies for these children. One pertinent aspect of the policy is to award certification to children who complete each grade in their learning centre. The long term, positive impact of education is compromised when student learning is not validated through official recognition (MacEwen, 2009). The value and quality of education programmes diminishes. Careful planning and co-ordination between the different actors involved in implementing and validating education programmes are essential. By effectively addressing certification issues, the quality, impact and sustainability of programmes are more likely to be guaranteed (ibid). As asked by a parent whose two children are in the learning centre:

I send my children to this place [learning centre] every day. Yes...they learn but what happens after they finish studying here? Can they go anywhere? They don't get any certificate when they finish studying here.

This concern is shared by many other parents too who wish to see their children being awarded recognised certification which would allow for mobility and enable them to have access to tertiary education or secure a proper job.

\section{The Way Forward}

It is clear that the educational needs of the Rohingya children in Malaysia deserve immediate attention. The case of Rohingya refugees is unique and should be treated differently from the other refugees. Firstly they are stateless, therefore they have little or no hope in returning unless some drastic changes in politics happen in Myanmar, and secondly no Rohingya refugees have been resettled so far (personal communication with UNHCR personnel). They are the longest living refugees in Malaysia, and most probably will go on living in this country for the next few decades. All parties concerned must be able to look into this situation realistically. A structured and stable learning environment equipped with the necessary tools is pivotal to compete but also cater for their psycho-social needs. The current situation as explained above is clearly insufficient. A quality education in this scenario needs to ensure that one of two outcomes takes place. Either the student is given a pathway that eventually leads to an internationally recognised Pre-University certificate e.g. International Baccalaureate (IB) or they are provided an alternate pathway that leads to skilled work or technical work. Either outcome may provide opportunity for the refugee child to be employed in today's modern and mobilised workforce. Quality education should empower the refugee children to be able to survive in the challenging world.

We want our children to get proper jobs here in Malaysia...to go to university here. My son wants to be a doctor and my daughter a teacher. (Refugee parent, from interview, translated) 
I have been living in Malaysia for 32 years. All these years I have been doing odd jobs to survive and take care of my family. Life is tough. We are very poor. Often we eat only rice and salted fish. It is difficult to pay rental every month. I don't want my children to suffer like us too. Only education can help them. (Refugee parent, from interview, translated)

I am married to an Indonesian. So I don't think I have any chance of resettling to a third country. Our children were born here but they are not awarded citizenship. School gives hope to the children and parents that life in Malaysia for us will be normal in the future. (Refugee community school principal, from interview, translated)

Education without purpose disadvantages the student and the family as only uncertainty awaits after years of classroom schooling (IIEP-UNESCO, 2009). The movement by universities to offer online learning as alternate means has proven reasonably successful, for example Massachusetts Institute of Technology (MIT) and Yale University. A curriculum that is holistic and meets the requirements set out and can take advantage of technological advances might help refugee students obtain quality education. All that is needed is computer and access to internet, amenities that are considered basic and available cheaply and easily. Although there are obvious drawbacks with remote or even blended learning, the benefits are easily seen as the students will have access to what is universally regarded as quality materials. The teacher who is already onsite can play the role as administrator to ensure that lessons take place. The BRAC ${ }^{4}$ system in Bangladesh and Bridge International Academy ${ }^{5}$ in Kenya for impoverished children provide an existing model that can be further enhanced to cater for the needs of refugee children in Malaysia. Joint efforts with the government and United Nations sponsored NGOs might lead to a stabilising influence on refugee communities. Funding which has gone to resettling and supporting learning centres can instead be used for these purposes which are more sustainable.

\section{Notes}

1 Madrasah is an educational institution for the study of Islamic religion, usually placed in the mosques for students from the neighbourhood.

2 Bangladesh has experienced two major influxes of refugees from Myanmar, mostly the Rohingya; first in 1978 and the second in 1991-92. A large scale of expatriation exercise followed after each influx, which was mainly involuntary.

3 The interviews were conducted as part of the research funded by the University of Malaya Research Grant (UMRG) to determine the quality of education in the refugee learning centres in Malaysia. The outcome of this research was shared with UNHCR to assist them in implementing better standards to improve the quality of education in these refugee learning centres.

$4 \quad$ BRAC is the largest non-governmental development organisation in the world established to alleviate poverty. It reaches out to children who have been excluded from the mainstream education due to extreme poverty, violence, gender discrimination and displacement.

5 Bridge International Academy provides low-cost, high quality education to families living on less than USD\$2 per day. It uses the model Academy-in-a-box to reduce the investments often needed to build a school, including staff, infrastructure and developing curriculum.

\section{Reference}

ActAlliance (2011). Community-based Psychosocial Support in Emergencies. Available at htt p:// psychosocial.actalliance.org/default.aspx?di=66160. [Accessed on 5 July 2013].

American Institute for Research (1999). Educational Quality Framework. Available at www.ieq.org/ pdf/EducQualFramework.pdf. [Accessed on 10 May 2013].

Bereiter, C. \& Scardamalia, M. (1993). Surpassing Ourselves. Open Court Publishing.

Brock, C \& McCorriston, M. (2008). Towards the Concept of Education as a Humanitarian Response in the Context of a UNESCO chair/UNITWIN network. London: UK National Commission for UNESCO.

Brock, C. (2011). Education as a Global Concern. London: Continuum. 
Chan, A. (2005). The Development of a Muslim Enclave in Arakan (Rakhine) State of Burma (Myanmar). SOAS Bulletin of Burma Research, 3(2). Available at www.soas.ac.uk/sbbr/editions/file64388. pdf. [Accessed on 5 June 2013].

Concern Bangladesh (2001) Annual Report 2000: Rohingya Refugee Programme, Cox's Bazar. pg.9.

Craig,H. (1995). School Effectiveness and School Improvement in the Pacific: Policy and planning - focus on the school. Paper presented at the annual meeting of the Comparative and International Education Society, Boston.

Davies, L. (2011). Conflict and Education - Complexity and Chaos. London: Routledge Falmer.

Feeny, T. (2001). Rohingya Refugee Children in Cox Bazaar, Bangladesh. A Discussion Document Prepared for UNICEF Regional Office South Asia. Available at http://www.rsc.ox.ac.uk/pdfs/ workshop-conference-research-reports/CAAC\%20Rohingya\%20Report\%20Bangladesh\%20 final\%20report.pdf. [Accessed on 30 May 2013].

Gardner, H. (1983). Frames of Mind. New York: Basic Books.

Gardner,H. (1993). Mutiple Intelligences: The theory in practice. New York: Basic Books.

Garcia, S. \& Olson, C. (2008). Rohingya: Burma's Forgotten Minority. Available at "http:// refugeesinternational.org/policy/field-report/rohingya-burma\%E2\%80\%99s-forgottenminority" http://refugeesinternational.org/policy/field-report/rohingya-burma\%E2\%80\%99sforgotten-minority. [Accessed on 7 June 2013].

Haque, M. (2011). Undocumented Rohingya Refugees in Bangladesh: Government Justification of the Policies on their Basic Rights and Human Security. Available at www.humanrights-mu.org/ attachments/article/88/1c\%20Mahbubul.pdf'Cached. [Accessed on 5 June 2013].

Human Rights Watch (2012). Bangladesh: Letter to Prime Minister Sheikh Hasina Regarding Obligations not to Reject Refugees. Available at http://www.hrw.org/news/2012/06/15/ bangladesh-letter-prime-minister-sheikh-hasina-regarding-obligations-not-reject-refu. [Accessed on 1 June 2013].

IIEP-UNESCO (2009). Certification Counts - Recognizing the learning attainments of displaced and refugee students. Paris: IIEP-UNESCO.

INEE (2007). Talking Points - Education in Emergencies and the INEE Minimum Standards. Available at http://www.ineesite.org/uploads/files/resources/doc_1_EmergencyResponseTalkingPoints. pdf. [ Accessed on 7 August 2013].

INEE (2010). Minimum Standards for Education. Preparedness, Response, Recovery. Available at www.ineesite.org. [Accessed on 15 April 2013].

Kiragu, E., Rosi, A.I. \& Morris, T. (2011). States of Denial - A review of UNHCR's response to the protracted situation of stateless Rohingya refugees in Bangladesh. Available at www.unhcr. org/4ee754c19.pdf. [Accessed on 5 June 2013].

Letchamanan,H. (2010). Needs and responses: a study of education for refugee and migrant children in Malaysia. M.Sc. Dissertation University of Oxford. Oxford: University of Oxford Press.

Levinger, B. (1994). Nutrition, Health and Education for All. Newton, MA: Education Development Center.

MacEwen,L. (2009). Certification Counts - Recognizing the learning attainments of displaced and refugee students. Paris: IIEP- UNESCO.

MSF (2010). Bangladesh - Violence Crackdown Fuels Humanitarian Crisis for Unrecognized Rohingya Refugees. Available at www.doctorswithoutborders.org/publications/article.cfm?id=4270. [Accessed on 1 June 2013].

Oh, S.A. (2010). Education in Refugee Camps in Thailand: policy, practice and paucity. Paper commissioned for the Education for All Global Monitoring Report 2011, The hidden crisis: Armed Conflict and Education.

O’Toole (February 12, 2013) Refugee Limbo for Thousands of Rohingya in Thailand. Available at http://www.rohingya.org/portal/index.php/rohingya-library/32-refugee/492-refugee-limbofor-thousands-of-rohingya-in-thailand-.html. [Accessed on 30 May 2013]. 
Perkins, D. (1995). Outsmarting IQ: The emerging science of learnable intelligence. New York: Free Press.

Preston, R. (2001). The Provision of Education to Refugees in Places of Temporary Asylum: Some Implications for Development. Comparative Education, 27(1) pp.61-81.

Radio Free Asia (April 29, 2013). Rohingya: The World's Least Wanted People. Available at http:// www.rfa.org/english/news/special/rohingya. [Accessed on 5 May 2013].

Rahman, H. (2009). Brief Situation Report of Rohingya Refugees in Malaysia. On the Occasion of World Refugee Day. Kuala Lumpur: Arakan Rohingya Refugee Committee (ARRC).

Refugee International (2012). Myanmar, Bangladesh Trample on Rohingya Rights. Available at http:// www.refintl.org/press-room/press-release/myanmar-bangladesh-trample-rohingya-rights [Accessed on 13 May 2013].

Reuters (February 9, 2013). After Myanmar Violence, Almost 6000 Rohingyas arrive in Thailand. Available at http://in.reuters.com/article/2013/02/07/thailand-rohingya-muslims-myanmaridINDEE91607A20130207. [Accessed on 3 June 2013].

Robinson, I.G. \& Rahman, I.S. (2012). The Unknown Fate of the Stateless Rohingya. Oxford Monitor of Forced Migration, 2(2). Available at oxmofm.com/wp- content/uploads/.../Robinson-andRahman-FINAL.pdfCached. [Retrieved on 5 June 2013].

Sinclair, M. (2007). Education in Emergencies. Available at: http://www.cedol.org/wp- content/ uploads/2012/02/52-56-2007.pdf. [Accessed on 1 July 2013].

SPDC (2010). Rakhine State Population Figured by SPDC. Available at http://www.narinjara.com/ detailsbur.asp?id=2689. [Accessed on 13 April 2013].

The Dakar Framework for Action (2000). Education for All: Meeting our collective commitments. Available at: http://unesdoc.unesco.org/images/0012/001211/121147e.pdf. [Accessed on 20 June 2013].

The Economist (November 3, 2012). Why Buddhists and Muslims in Rakhine State in Myanmar are at Each Other's Throat. Available at http://www.economist.com/news/asia/21565638why-buddhists-and-muslims-rakhine-state-myanmar-are-each-others\%E2\%80\%99-throatsunforgiving. [Accessed on 5 June 2013].

The Star (June 11, 2013). Ethnic-based Clashes in Myanmar Spill Over to Streets in Kuala Lumpur. Available at http://thestar.com.my/news/story.asp?file=/2013/6/11/nation/2013061118530 0\&sec=nation. [Accessed on 12 June 2013].

UNHCR (2011). States Parties to the1951 Convention relating to the Status of Refugees and the 1967 Protocol. Available at http://www.unhcr.org/3b73b0d63.html. [Retrieved on 5 July 2013].

UNHCR (2013a). Figures at a Glance. Available at http://www.unhcr.org.my/About_Us-@-Figures_ At_A_Glance.aspx. [Accessed on 10 June 2013].

UNHCR (2013b). Refugee Figures. Available at http://www.unhcr.org/pages/49c3646c1d.html. [Accessed on 1 July 2013]. 